\title{
Association between arterial hypertension and chronic obstructive pulmonary disease: role of AGT gene polymorphism
}

Mariya Marushchak ${ }^{1, *}$, Khrystyna Maksiv², Inna Krynytska ${ }^{3}$, Kateryna Kozak ${ }^{4}$

${ }^{1}$ Department of Functional and Laboratory Diagnostics, I. Horbachevsky Ternopil National Medical University, 46001 Ternopil, Ukraine.

E-mail: marushchak@tdmu.edu.ua

${ }^{2}$ Department of Medical Rehabilitation, I. Horbachevsky Ternopil National Medical University, 46001 Ternopil, Ukraine.

E-mail: maksivhrustuna@gmail.com

${ }^{3}$ Department of Functional and Laboratory Diagnostics, I. Horbachevsky Ternopil National Medical University, 46001 Ternopil, Ukraine.

E-mail: krynytska@tdmu.edu.ua

Abstract

${ }^{4}$ Department of Pediatrics N 2, I. Horbachevsky Ternopil National Medical University, 46001 Ternopil, Ukraine. E-mail: katerynakozak11@gmail.com

English:

Background: Chronic obstructive pulmonary disease (COPD) continues to cause a heavy health and economic burden in the Europe and around the world. Arterial hypertension (AH) is considered as one of the principal COPD-associated comorbidities. However, no data for association between gene polymorphism and AH in patients with COPD in Ukraine have ever been internationally published. We assessed the genotype and allele frequencies of angiotensinogen (AGT) M235T polymorphisms in patients with COPD and comorbid $\mathrm{AH}$.

Methods: The study group consisted of 96 patients: Group 1 (25 individuals with COPD), Group 2 (23 individuals with AH) and Group 3 (28 individuals with COPD and AH). The control group consisted of 20 healthy subjects. M/T genotypes of AGT were determined by polymerase chain reaction amplification.

Results: The results of the study have not demonstrated any significant impact of alleles of AGT genes on the occurrence of diseases such as COPD, AH and combinations thereof. However, analysis of odds ratio has demonstrated the presence of a trend towards a protective role of the $M$ allele of the AGT gene concerning occurrence of COPD, AH and their combinations. At the same time, the presence of the $T$ allele of the AGT gene may increase the risk for occurrence of the above-mentioned diseases. Conclusions: The study that we have conducted suggests that the presence of T allele of the AGT gene at position 235 of the peptide chain both in homozygous and heterozygous states may increase the risk for AH in patients with COPD.

Keywords

chronic obstructive pulmonary disease $\bullet$ arterial hypertension • angiotensinogen gene

\section{Asociere între hipertensiunea arterială și boala pulmonară obstructivă cronică: rolul polimorfismului genic AGT}

Rezumat

\begin{abstract}
Romanian:
Context general: Boala pulmonară obstructivă cronică (BPOC) continuă să rămână o povară pentru sistemele de sănătate și pentru economie la nivel mondial. Hipertensiunea arterială (HTA) este considerată una dintre comorbiditățile majore asociate cu BPOC. Cu toate acestea, nu au fost publicate la nivel internațional date privind asocierea între polimorfismul genic și hipertensiunea arterială la pacienții cu BPOC din Ucraina. Am evaluat genotipul și frecvențele de alele ale polimorfismelor AGT M235T la pacienții cu boală pulmonară obstructivă cronică și hipertensiune arterială comorbidă.
\end{abstract}

${ }^{*}$ Corresponding author: Mariya Marushchak

E-mail: marushchak@tdmu.edu.ua; Tel.: +380979981202

ə Open Access. ๑ 2019 Marushchak et al., published by Sciendo

(@) Br.Nc-ND This work is licensed under the Creative Commons Attribution-NonCommercial-NoDerivs 4.0 License. 
Metode: Grupul de studiu a fost format din 96 de pacienți: Grupul 1 (25 de persoane cu BPOC), Grupul 2 (23 de persoane cu HTA), Grupul 3 (28 de persoane cu BPOC și HTA). Grupul de control a fost format din 20 de subiecți sănătoși. Genotipurile M/T ale AGT au fost determinate prin amplificarea reactiei în lant a polimerazei.

Rezultate: Rezultatele studiului nu au demonstrat nici un impact semnificativ al alelelor genelor AGT asupra apariției unor boli precum BPOC, HTA și combinații ale acestora. Cu toate acestea, analiza ratelor de probă a demonstrat prezența unei tendinte către un rol protector al alelei M a genei AGT în ceea ce privește apariția BPOC, HTA și a combinațiilor acestora. În același timp, prezenta alelei T a genei AGT poate creste riscul aparitiei bolii mentionate mai sus.

Concluzii: Studiul pe care l-am realizat sugerează că prezența alelei T a genei AGT la poziția 235 a lanțului peptidic atât în stări homozigote, cât și heterozigote poate crește riscul de HTA la pacienții cu BPOC.

Cuvinte-cheie

boală pulmonară obstructivă cronică • hipertensiune arteriala • gena angiotensinogenă

\section{Introduction}

The Global Burden of Disease Study estimated that chronic obstructive pulmonary disease (COPD) affected 251 million people worldwide and was the third leading cause of death in 2016, causing more than three million deaths (1). The prevalence of COPD in Europe has been estimated to range between $4 \%$ and 10\%, and between 1994 and 2010, 2,348,184 deaths were attributed to COPD in the European Union (2). Ukraine is characterized with extremely high COPD mortality rates compared with other European countries: while the number of deaths per 100,000 of population is less than 20 in Greece, Sweden, Iceland and Norway, it is more than 80 in Ukraine (3). Despite high mortality rates, very limited epidemiological COPD data are available in Ukraine. The CORE study conducted across major cities in Ukraine, Kazakhstan and Azerbaijan from the first half of 2013 until the end of 2015 has showed that prevalence of COPD diagnosed by spirometry (based on the Global Initiative for Chronic Obstructive Lung Disease guideline, 2011; forced expiratory volume in $1 \mathrm{~s}\left[\mathrm{FEV}_{1}\right] /$ forced vital capacity $[\mathrm{FVC}]<0.70)$ was $31.9(95 \%$ confidence interval [Cl] 21.7-45.3) per 1,000 of population in Ukraine (4).

COPD is a complex respiratory disorder, which affects the course and development of some concomitant diseases; this makes COPD a systemic disorder (5). As expected, the most significant correlation was found between COPD and cardiovascular diseases (CVDs), whose prevalence is a global health problem that leads to impaired quality of life and shortens life expectancy (6-7). Arterial hypertension (AH) is a part of CVDs that symbolize the highest proportion of disease-related mortality causes such as cerebral vascular accident and acute myocardial infarction, reaching about two-fifths of the adult population in developed countries (8). $\mathrm{AH}$ is considered as one of the principal COPD-associated comorbidities. A population study has shown $\mathrm{AH}$ to be the highest prevalence comorbidity in patients with COPD among the 82 studied comorbidities (24\%) (9). Similar results were reported in the Fifth Korean National Health and Nutrition Examination Survey study, where only $\mathrm{AH}$ and history of pulmonary tuberculosis were independently associated with COPD among different 15 comorbidities (10). Another study showed that COPD is found in $25 \%$ of patients with CVDs (11). Comorbidity analysis suggests the need for active strategies looking for correlations between COPD and the incidence of $\mathrm{AH}$.

Both hypertension and COPD are genetically determined conditions with multiple genes, combinations of genes, intergene interactions and epigenetic processes responsible for their occurrence (12). The renin-angiotensin system (RAS), the sympathetic nervous system, sodium and electrolyte balance and intracellular messengers have all been suggested to play an important role in the regulation of blood pressure and pathogenesis of $\mathrm{AH}$. Thus, polymorphisms of RAS genes that encode angiotensinogen (AGT), angiotensin-converting enzyme (ACE) and angiotensinogen II type-1 receptor have been extensively investigated as potential loci for $\mathrm{AH}$ (13-14). The AGT gene is an important vascular lesion-related factor (15). It is located in the $1 \mathrm{q} 42-43$ region of the long arm of chromosome 1 and has a total length of $13 \mathrm{~kb}$; the gene coding region is composed of five exons and four introns (16). Although other researches have identified the relations of gene polymorphisms in RAS with different clinical settings (17-21), we could not observe any report about AGT M235T polymorphism in patients with COPD. We believe eliminating RAS genes polymorphisms in COPD can provide benefits to improve clinical treatments and help us understand COPD pathophysiology and development of comorbidities.

Thus, the aim of this study was to establish the genotype and allele frequencies of AGT M235T polymorphisms in patients with COPD and comorbid $\mathrm{AH}$. 


\section{Methods}

The study group consisted of 96 patients admitted to the Ternopil University Hospital. We stratified patients into three groups: Group 1 (25 patients with COPD), Group 2 (23 patients with $\mathrm{AH}$ ) and Group 3 (28 patients with COPD + $\mathrm{AH})$. The control group consisted of 20 healthy subjects.

\section{Inclusion criteria}

The inclusion criteria included male patients 40-60 years of age at screening with a diagnosis of COPD and/or $\mathrm{AH}$ and informed consent form signed by patients prior to their participation in any study-related procedures. COPD was diagnosed according to Order 555 of Ministry of Health of Ukraine dated 27 June 2013 and according to the guidelines published by the American Thoracic Society and European Respiratory Society (GOLD, 2013). Airway obstruction was assessed using GOLD classification, 2008. The diagnosis of COPD with moderate (Stage 2) airway obstruction was confirmed with compatible clinical features concurrent with airflow limitation defined as $\mathrm{FEV}_{1} / \mathrm{FVC}$ less than $0.70\left(\mathrm{FEV}_{1} /\right.$ FVC ratio of $50-79 \%$ predicted).

The diagnosis of $\mathrm{AH}$ (Stage I) was made according to 2018 European Society of Cardiology/European Society of Hypertension (ESC/ESH) Guidelines for the management of $\mathrm{AH}$ (21). Systolic $(140-159 \mathrm{mmHg})$ and/or diastolic (90-99 $\mathrm{mmHg}$ ) blood pressure were considered as the presence of Stage I $\mathrm{AH}$. Left ventricular hypertrophy was confirmed by an electrocardiogram.

\section{Exclusion criteria}

The exclusion criteria were patients with bronchial asthma; a1-antitrypsin deficiency; active tuberculosis; lung cancer; significant bronchiectasis; sarcoidosis; pulmonary fibrosis; interstitial lung disease; signs and symptoms of clinically significant neurological, psychiatric, renal, hepatic, immunological, gastrointestinal and urogenital disorders; musculoskeletal conditions; disorders of the skin and sensory organs; endocrine disorders (uncontrolled diabetes or thyroid disease) or uncontrolled haematological disease; unstable liver disease and unstable or life-threatening heart disease; cancer patients not completely disease-free for a minimum of 5 years and patients with any drug, substance or alcohol abuse.

Sampling of venous blood for genotyping was performed under sterile conditions into $2.7 \mathrm{~mL}$ Monovettes with potassium salt of ethylenediaminetetraacetic acid as an anticoagulant; the samples were frozen and stored at $-20^{\circ} \mathrm{C}$. Molecular genetic studies were performed with extraction of DNA and with use of polymerase chain reaction (PCR) and further analysis for the length of restriction fragments. DNA was extracted from peripheral blood leukocytes using a standard salt precipitation method. Genotyping for the AGT
M235T was performed using PCR-based restriction fragment length polymorphism (RFLP). The primers used were 5'CCGTTTGTGCAGGGCCTGGCTCTCT-3' (forward) and 5'-TGC TGT CCA CAC TGG ACC CC-3' (reverse). The PCR products were digested with $3 \mathrm{U}$ of Tth111I (Fermentas), and the fragments were separated on a $3 \%$ agarose gel. Diagnostic fragments were visualized by ethidium bromide staining and ultraviolet transillumination. The heterozygous form $(M / T)$ was indicated by the appearance of two fragments of 165 and $141 \mathrm{bp}$, while the homozygous form revealed only one band of $141 \mathrm{bp}(\mathrm{T} / \mathrm{T})$ and individuals lacking this mutation showed only one band of $165 \mathrm{pb}(\mathrm{M} / \mathrm{M})$. To assess genotyping reliability, we performed double-sampling PCR-RFLP in more than $20 \%$ of the samples and found no differences (14).

\section{Statistical analysis}

Statistical data analysis was carried out using Statistica 7.0 software. Assessment of genotypes of the selected sample for conformity to general population sample was guided by the Hardy-Weinberg principle. The observed frequencies and the expected frequencies calculated from the expression $p^{2}+2 p q+$ $q^{2}=1$ (Hardy-Weinberg equilibrium) were compared using the Pearson chi-square $\left(\chi^{2}\right)$ test. In case of probability value $p>0.05$, a null hypothesis of equal samples was accepted, i.e. that the selected sample was equivalent to the general population.

Comparative analysis of frequency tables was performed using Pearson chi-square $\left(\chi^{2}\right)$ and Fisher's exact $p$ (twotailed) tests (in cases when expected frequencies of individual parameters did not exceed 5).

To assess the impact of the factor (the presence of a certain genotype or an allele of a gene) on the occurrence of the disease, odds ratio (OR) and its $95 \% \mathrm{Cl}$ and probability value $p$ were calculated.

\section{Results}

The frequency distribution of polymorphic genotypes of the gene encoding angiotensinogen and assessment of compliance with the Hardy-Weinberg population equilibrium were carried out in groups of patients with COPD, $\mathrm{AH}$ and $\mathrm{COPD}+\mathrm{AH}$ combination. A deviation from the HardyWeinberg equilibrium was found in the group of patients with COPD due to a lower rate of heterozygotes than theoretically expected (Table 1).

The deviation from the Hardy-Weinberg equilibrium in the group of patients with COPD is potentially attributable to the heterogeneity of the patient population. The frequencies of the genotype responsible for the $\mathrm{M} / \mathrm{T}$ polymorphism of the AGT gene in the control group and in Groups 2 and 3 were 
not found to deviate significantly from the Hardy-Weinberg equilibrium ( $p>0.05$; Table 1). The respective frequencies for the genotypes of the AGT gene were as follows: $24.0 \%$ for $\mathrm{M} / \mathrm{M}, 75.0 \%$ for $\mathrm{M} / \mathrm{T}$ and $1.8 \%$ for $\mathrm{T} / \mathrm{T}$ in Test Group 1 with COPD; $26.1 \%$ for $\mathrm{M} / \mathrm{M}, 56.5 \%$ for $\mathrm{M} / \mathrm{T}$ and $17.4 \%$ for $\mathrm{T} / \mathrm{T}$ in Group 2 with $\mathrm{AH} ; 25.0 \%$ for $\mathrm{M} / \mathrm{M}, 46.4 \%$ for $\mathrm{M} / \mathrm{T}$ and $28.6 \%$ for $\mathrm{T} / \mathrm{T}$ in Group 3 with COPD $+\mathrm{AH}$ and $30.0 \%$ for $\mathrm{M} / \mathrm{M}, 65.0 \%$ for $\mathrm{M} / \mathrm{T}$ and $5.0 \%$ for $\mathrm{T} / \mathrm{T}$ in the control group (Table 2).

The frequencies of alleles for the AGT gene in patients with COPD, $\mathrm{AH}$ and $\mathrm{COPD}+\mathrm{AH}$ and control group patients are given in Table 3. In the COPD group, the established distribution was AGT M allele (60.0\%) and AGT T allele $(40.0 \%)$; the respective distributions were $54.3 \%$ and $45.7 \%$ in the AH group, $48.2 \%$ and $51.8 \%$ in the COPD + $\mathrm{AH}$ group and $62.5 \%$ and $37.5 \%$ in the control group, with no significant differences across test groups and the control group.

The results of the study given in Table 4 have demonstrated absence of a statistically significant relationship between the factor (presence of $\mathrm{M} / \mathrm{T}$ alleles) and occurrence of the disease $(p>0.05)$.

Assessment of the probability value as part of analysis of OR has demonstrated absence of influence of a certain genotype on the occurrence of the disease $(p>0.05$; Table 5).

The results of the study have not demonstrated any significant impact of alleles of AGT genes on the occurrence of diseases such as COPD, AH and combinations thereof. However, analysis of OR has demonstrated the presence of a trend towards a protective role of the $M$ allele of the AGT gene concerning the occurrence of COPD, $\mathrm{AH}$ and their combinations $(\mathrm{OR}=0.90, \mathrm{OR}=0.71$ and $\mathrm{OR}=0.56$, respectively). At the same time, the presence of the $T$ allele of the AGT gene may increase the risk for the occurrence of the above-mentioned disease $(\mathrm{OR}=1.11$, $\mathrm{OR}=1.4$ and $\mathrm{OR}=1.79$, respectively).

This is confirmed by a significant difference found when building a recessive inheritance model in combination of COPD and $\mathrm{AH}$ (Table 6). In a dominant model of

Table 1. Hardy-Weinberg equilibrium of the AGT gene M/T polymorphism in COPD, AH and their combination

\begin{tabular}{|c|c|c|c|c|c|c|c|c|c|}
\hline \multirow[t]{2}{*}{ Genotype } & & \multicolumn{2}{|c|}{ COPD } & \multicolumn{2}{|c|}{$\mathrm{AH}$} & \multicolumn{2}{|c|}{$\mathrm{COPD}+\mathrm{AH}$} & \multicolumn{2}{|c|}{ Control } \\
\hline & & Expected & Observed & Expected & Observed & Expected & Observed & Expected & Observed \\
\hline Common homozygotes & $\mathrm{M} / \mathrm{M}$ & 9 & 6 & 6.8 & 6 & 6.5 & 7 & 7.8 & 6 \\
\hline Heterozygotes & $\mathrm{M} / \mathrm{T}$ & 11.8 & 18 & 11.4 & 13 & 14 & 13 & 9.4 & 13 \\
\hline Rare homozygotes & $T / T$ & 4.2 & 1 & 4.8 & 4 & 7.5 & 8 & 2.8 & 1 \\
\hline Chi-square $\left(\chi^{2}\right)$ & & \multicolumn{2}{|c|}{$\chi^{2}=6.70, \mathrm{df}=2, p<0.04$} & \multicolumn{2}{|c|}{$\chi^{2}=0.45, \mathrm{df}=2, p>0.05$} & \multicolumn{2}{|c|}{$\chi^{2}=0.14, \mathrm{df}=2, p>0.05$} & \multicolumn{2}{|c|}{$\chi^{2}=2.95, \mathrm{df}=2, p>0.05$} \\
\hline
\end{tabular}

$\mathrm{AGT}$, angiotensinogen; COPD, chronic obstructive pulmonary disease; $\mathrm{AH}$, arterial hypertension.

Table 2. Genotype frequencies of the AGT gene M/T polymorphism in COPD, AH and their combination

\begin{tabular}{|c|c|c|c|c|c|c|c|c|}
\hline \multirow[t]{2}{*}{ Genotype frequencies } & \multicolumn{2}{|c|}{ COPD } & \multicolumn{2}{|c|}{$\mathrm{AH}$} & \multicolumn{2}{|c|}{ COPD + AH } & \multicolumn{2}{|c|}{ Control } \\
\hline & $\mathrm{n}$ & $\%$ & $\mathrm{n}$ & $\%$ & $\bar{n}$ & $\%$ & $\mathrm{n}$ & $\%$ \\
\hline $\mathrm{M} / \mathrm{M}$ & 6 & 24.0 & 6 & 26.1 & 7 & 25.0 & 6 & 30.0 \\
\hline$M / T$ & 18 & 72.0 & 13 & 56.5 & 13 & 46.4 & 13 & 65.0 \\
\hline $\mathrm{T} / \mathrm{T}$ & 1 & 4.0 & 4 & 17.4 & 8 & 28.6 & 1 & 5.0 \\
\hline $\begin{array}{l}\text { Fisher's exact } p \\
\text { (two-tailed; disease/ } \\
\text { control group) }\end{array}$ & \multicolumn{2}{|c|}{$p=0.75$} & \multicolumn{2}{|c|}{$p=0.76$} & \multicolumn{2}{|c|}{$p=0.25$} & \multicolumn{2}{|c|}{-} \\
\hline
\end{tabular}

AGT, angiotensinogen; COPD, chronic obstructive pulmonary disease; $\mathrm{AH}$, arterial hypertension.

Table 3. Allele frequencies of the AGT gene M/T polymorphism in COPD, AH and their combination

\begin{tabular}{|c|c|c|c|c|c|c|c|c|}
\hline \multirow[t]{2}{*}{ Allele frequency } & \multicolumn{2}{|c|}{ COPD } & \multicolumn{2}{|c|}{$\mathbf{A H}$} & \multicolumn{2}{|c|}{ COPD + AH } & \multicolumn{2}{|c|}{ Control } \\
\hline & $\mathbf{n}$ & $\%$ & $\mathrm{n}$ & $\%$ & $\mathrm{n}$ & $\%$ & $n$ & $\%$ \\
\hline AGT M allele & 30 & 60.0 & 25 & 54.3 & 27 & 48.2 & 25 & 62.5 \\
\hline AGT T allele & 20 & 40.0 & 21 & 45.7 & 29 & 51.8 & 15 & 37.5 \\
\hline $\begin{array}{l}\text { Pearson chi-square } \\
\text { ( } \chi^{2} ; \text { disease/control group) }\end{array}$ & \multicolumn{2}{|c|}{$\chi^{2}=0.06, \mathrm{df}=1, p=0.81$} & \multicolumn{2}{|c|}{$\chi^{2}=0.58, \mathrm{df}=1, p=0.44$} & \multicolumn{2}{|c|}{$\chi^{2}=1.92, \mathrm{df}=1, p=0.17$} & \multicolumn{2}{|c|}{-} \\
\hline
\end{tabular}

$\mathrm{AGT}$, angiotensinogen; COPD, chronic obstructive pulmonary disease; $\mathrm{AH}$, arterial hypertension. 
inheritance of the AGT gene in combination of COPD and $\mathrm{AH}$, no significant differences from the control group have been detected (the probability value for chi-square: $p>$ 0.05 ); however, in this setting, there is also a trend towards increased probability of the occurrence of disease in the presence of the T allele (Table 7). Therefore, the presence of the $T$ allele (both in homozygous and heterozygous states) may increase the risk for the above-mentioned diseases.

In groups of subjects without combined disease (in the group of patients with COPD and in the group of patients with $\mathrm{AH})$, no significant differences were found in the analysis of dominant and recessive types of inheritance for the AGT gene ( $\mathrm{M}$ and $\mathrm{T}$ alleles) (in these cases, the probability value for $\chi^{2}$ was $p>0.05$ ).

\section{Discussion}

COPD is a heterogeneous condition that has a single common denominator: chronic airflow obstruction. Because currently available treatments have minimal impact on disease progression, a strategy to prevent the development of COPD is a critical priority. Personal direct

Table 4. OR for alleles in different study groups

\begin{tabular}{|c|c|c|c|c|c|c|}
\hline \multirow{3}{*}{ Group } & \multicolumn{6}{|c|}{ Alleles } \\
\hline & \multicolumn{3}{|c|}{ AGT M allele } & \multicolumn{3}{|c|}{ AGT T allele } \\
\hline & OR & $95 \% \mathrm{Cl}$ & $p$ & OR & $95 \% \mathrm{Cl}$ & $p$ \\
\hline COPD & 0.90 & $0.38-2.11$ & $>0.05$ & 1.11 & $0.47-2.61$ & $>0.05$ \\
\hline $\mathrm{AH}$ & 0.71 & $0.3-1.69$ & $>0.05$ & 1.4 & $0.59-3.32$ & $>0.05$ \\
\hline $\mathrm{COPD}+\mathrm{AH}$ & 0.56 & $0.24-1.28$ & $>0.05$ & 1.79 & $0.78-4.09$ & $>0.05$ \\
\hline
\end{tabular}

$\mathrm{OR}$, odds ratio; $\mathrm{AGT}$, angiotensinogen; $\mathrm{Cl}$, confidence interval; COPD, chronic obstructive pulmonary disease; $\mathrm{AH}$, arterial hypertension.

Table 5. OR for genotypes in different study groups

\begin{tabular}{|c|c|c|c|c|c|c|}
\hline \multirow{3}{*}{ Group } & \multicolumn{6}{|c|}{ Genotype } \\
\hline & \multicolumn{2}{|c|}{$\mathrm{M} / \mathrm{M}$} & \multicolumn{2}{|c|}{$M / T$} & \multicolumn{2}{|c|}{$T / T$} \\
\hline & OR & $95 \% \mathrm{Cl}$ & OR & $95 \% \mathrm{Cl}$ & OR & $95 \% \mathrm{Cl}$ \\
\hline COPD & 0.74 & $0.20-2.77$ & 1.38 & $0.39-4.92$ & 0.79 & $0.05-13.5$ \\
\hline $\mathrm{AH}$ & 0.82 & $0.22-3.13$ & 0.70 & $0.20-2.41$ & 4.00 & $0.41-39.18$ \\
\hline $\mathrm{COPD}+\mathrm{AH}$ & 0.78 & $0.22-2.81$ & 0.47 & $0.14-1.52$ & 7.60 & $0.87-66.67$ \\
\hline
\end{tabular}

Notes: $p$ coefficient for $\mathrm{OR}-p+0.05$ in all cases.

$\mathrm{OR}$, odds ratio; $\mathrm{Cl}$, confidence interval; COPD, chronic obstructive pulmonary disease; $\mathrm{AH}$, arterial hypertension.

Table 6. A recessive model of the AGT gene inheritance in combination of COPD and AH

\begin{tabular}{|c|c|c|c|c|c|c|}
\hline \multirow{2}{*}{ Genotypes } & COPD + AH & Control & \multirow{2}{*}{$x^{2}$} & \multirow{2}{*}{$p$} & \multirow{2}{*}{ OR } & \multirow{2}{*}{$95 \% \mathrm{Cl}$} \\
\hline & $\%$ & $\%$ & & & & \\
\hline $\mathrm{M} / \mathrm{M}+\mathrm{M} / \mathrm{T}$ genotype & 71.4 & 95.0 & 4.25 & 0.04 & 0.13 & $0.01-1.15$ \\
\hline $\mathrm{T} / \mathrm{T}$ genotype & 28.6 & 5.0 & & & 7.60 & $0.87-66.67$ \\
\hline
\end{tabular}

AGT, angiotensinogen; COPD, chronic obstructive pulmonary disease; $\mathrm{AH}$, arterial hypertension; OR, odds ratio; $\mathrm{Cl}$, confidence interval.

Table 7. A dominant model of AGT gene inheritance in combination of COPD and AH

\begin{tabular}{|c|c|c|c|c|c|c|}
\hline Genotypes & COPD + AH & Control & \multirow{2}{*}{$x^{2}$} & \multirow{2}{*}{$p$} & \multirow{2}{*}{ OR } & \multirow{2}{*}{$95 \% \mathrm{Cl}$} \\
\hline & $\%$ & $\%$ & & & & \\
\hline M/M genotype & 25.0 & 30.0 & \multirow{2}{*}{0.15} & \multirow{2}{*}{0.7} & 0.78 & $0.22-2.81$ \\
\hline $\mathrm{M} / \mathrm{T}+\mathrm{T} / \mathrm{T}$ genotype & 75.0 & 70.0 & & & 1.29 & $0.36-4.64$ \\
\hline
\end{tabular}

$\mathrm{AGT}$, angiotensinogen; COPD, chronic obstructive pulmonary disease; $\mathrm{AH}$, arterial hypertension; OR, odds ratio; $\mathrm{Cl}$, confidence interval. 
cigarette smoking is the most important single causal factor for developing COPD (22); however, only a small fraction of smokers develops a clinical presentation of COPD (23). Analysis of literature suggests that other risk factors biologically interact with cigarette smoking and potentiate the development of airflow obstruction: genetic factors, longstanding asthma, outdoor air pollution, second-hand smoke exposure, biomass smoke and indoor air pollution, occupational exposures, diet and tuberculosis (24-28).

Complications and comorbidities are an important consideration to take into account when managing the process of shaping the models of prevention, diagnosis and treatment of COPD (29). As expected, the most significant correlation was found between COPD and CVDs. Actually, COPD was found to be a predecessor of CVDs $(6,30)$. Frequent combinations of and interactions between these conditions may be attributable to several causes due to the presence of common links of pathogenesis (31). As a result of pulmonary tissue inflammation in COPD, molecules with proinflammatory, profibrous, procoagulant and vasoconstrictor effects are released into systemic circulation. These molecules are capable of modifying endothelial function, thereby creating conditions for a persistent elevation of blood pressure (32). On the other hand, hyperactivation of neurohormonal systems such as RAS, which is typical for $\mathrm{AH}$, may be involved in pulmonary inflammation, as well as in remodelling of lung parenchyma and bronchioles. Via type 1 receptors in the lungs, angiotensin II promotes activation of immunocompetent cells and the discharge of proinflammatory cytokines; it also induces proliferation of fibroblasts and apoptosis of bronchial epithelium and activates the processes associated with oxidative stress (33).

The RAS is one of the main regulatory systems for blood pressure. It has also a role in cardiovascular remodelling and vascular tone (14). Gonzalez et al. found that the baseline plasma renin activity had a significant, independent, specific and direct long-term association with CVD mortality in subjects with hypertension (34). The angiotensinogen gene $(A G T)$ is localized on the long arm of chromosome 1 in 1q42-q43 locus and contains five exons and four introns. In the $A G T$ gene, the best studied variants include the polymorphic M235T and T174M variants. The T174M (rs4762) polymorphism is characterized by a replacement of threonine with methionine at position 174 in the peptide chain, which is caused by a point replacement of cytosine with thymine at position 521 of the AGT gene (C521T). The M235T (rs699) polymorphism is a replacement of methionine with threonine at position 235 of the peptide chain, which is caused by a point replacement of thymine with cytosine at position 704 of the $A G T$ gene $(T 704 C)(35,36)$. It has been reported that AGT M235T polymorphism is associated with the increased risk for systemic artery hypertension in Caucasian-Brazilians and that AGT M235T may be an independent risk factor for in-stent restenosis (37). Additionally, other AGT promoter polymorphisms, including G217A and A-6G, were significantly associated with stroke in patients with atrial fibrillation (38). At the same time, a meta-analysis of epidemiological findings revealed no correlation between polymorphism of M235T with hypertrophic cardiomyopathy in European populations, while in Asian populations, there has been an association with the sporadic form of hypertrophic cardiomyopathy (35).

The polymorphic variant included in our study was the singlenucleotide replacement of thymine with cytosine at position 704 of the second exon of the angiotensinogen gene, which leaded to the Met $\rightarrow$ Thr change at position 235 of the final product (M235T). The data that we have received suggest the absence of a significant impact of AGT alleles or AGT genes on the occurrence of diseases such as COPD, AH and their combination among the patients of the Ukrainian population. In another study conducted in Ukraine, which assessed haplotype frequencies depending on the studied polymorphic variants of the AGT gene in different age groups of women with $\mathrm{AH}$, no significant differences compared to controls have likewise been detected (39). A study by Simonyte et al. of the frequencies of AGT genotypes and alleles using a multivariate logistic regression analysis could not demonstrate any association between AGT M235T polymorphism and hypertension (40). Niu et al. also found no association of AH with AGTM235T polymorphisms, even after adjustment for age, gender or severity of the disease (41). Likewise, Caulfield et al. have not found any association with polymorphisms of the AGTM235T gene (42). However, according to the results obtained in a study by Mohana et al., the presence of $235 \mathrm{M} / 174 \mathrm{M}$ haplotype suggests an increased risk of $\mathrm{AH}$ in women (43). The first report on association of M235 T molecular variants with hypertension in Caucasians was presented by Jeunemaitre et al. (44). In a study of M235T (T704C) polymorphism, Sethi et al. have found that the presence of polymorphic alleles leads to a significant increase in angiotensin-I plasma levels, accompanied by an increase in angiotensin II levels; therefore, this polymorphism is considered to be associated with hypertension (45). The results of the study by Kolovou et al. suggest that only the frequency of the AGTM235T (rs699) variant was significantly different between patients with $\mathrm{AH}$ and controls (46). The results by Shamaa et al. have shown a positive risk of $\mathrm{AH}$ in the presence of $T$ allele in a homozygous or heterozygous state, suggesting a relationship between the polymorphism of AGT genes (M235T) and risk for hypertension in Egyptian subjects (47). This is why some studies confirm the association between AGT polymorphism and AT, while others disprove it.

The results of our study in a group of patients with COPD have shown a significant deviation from the Hardy-Weinberg 
equilibrium for the polymorphism of M235T AGT gene, which is consistent with the data given by Ayada et al. (14). The later authors attributed such result to a gene drift, having assumed that the rare $T / T$ genotype was causing a gene drift in the COPD population. It is quite possible that the $T$ allele is disappearing in the COPD population due to its negative impact, which can also be a sign of the correlation between the T/T genotype and the development of COPD. In our study, interesting results have been obtained for analysis of OR in combination of COPD and $\mathrm{AH}$. These results demonstrated a trend towards a protective role of the $\mathrm{M}$ allele of the AGT gene concerning the occurrence of COPD, $\mathrm{AH}$ and their combination, while the presence of the $T$ allele of the AGT gene could increase the risk for these conditions. A study on the role of $A G T$ polymorphism in the occurrence of $A H$ in COPD in Ukraine was conducted for the first time; virtually no data on this issue could be found in the available literature. The majority of the studies relate to the association of $1 / D$ polymorphism of the ACE gene with the risk for COPD (48-50). It is worth noting that the DD genotype of ACE is generally associated with increased circulating and cellular levels of ACE and increased cardiovascular risk (51). There are data on association of AGT polymorphism (M235T) with right ventricular hypertrophy in patients with severe COPD (23). The present study has some limitations that should be considered in the interpretation of our results: sample size is too small, that is why it is difficult to find significant relationships from the data; the inclusion in the study group only of patients with Stage 2 COPD and Stage I AH and the patients were not randomly selected, generating a potential selection bias. Therefore, we cannot rule out the hypothesis that the patients evaluated do not represent the whole population of COPD patients in the Ternopil region of Ukraine. However, our results reflect a more heterogeneous real-world population, representative of clinical practice.

\section{Conclusion}

The study that we have conducted suggests that the presence of $\mathrm{T}$ allele of the angiotensinogen gene at position 235 of the peptide chain both in homozygous and heterozygous states may increase the risk for $\mathrm{AH}$ in patients with COPD.

\section{Ethical approval}

The study protocol was approved by the Medical Ethics Committee of I. Horbachevsky Ternopil State Medical University (No 55-04/11/2019), and the study was conducted in accordance with the Declaration of Helsinki of 1975, as revised in 1983. Informed consent was obtained from all patients.

\section{Conflict of interest}

The author declares that there is no potential conflict of interest.

\section{References}

1. Mkorombindo T, Dransfield MT. Mepolizumab in the treatment of eosinophilic chronic obstructive pulmonary disease. International Journal of Chronic Obstructive Pulmonary Disease. 2019;14: 1779-1787.

2. López-Campos JL, Ruiz-Ramos M, Soriano JB. Mortality trends in chronic obstructive pulmonary disease in Europe, 19942010: A join point regression analysis. The Lancet Respiratory Medicine. 2014;2: 54-62.

3. Andreeva TI, Krasovsky KS. COPD morbidity and mortality in Ukraine after tobacco control policies implementation. Chronic Obstructive Pulmonary Disease: Open Access. 2016;1(1): 3.

4. NugmanovaD, FeshchenkoY, lashyna L, Gyrina O, MalynovskaK, Mammadbayov E, et al. The prevalence, burden and risk factors associated with chronic obstructive pulmonary disease in Commonwealth of Independent States (Ukraine, Kazakhstan and Azerbaijan): Results of the CORE study. BMC Pulmonary Medicine. 2018;18(1): 26.

5. Smith M, Wrobel J. Epidemiology and clinical impact of major comorbidities in patients with COPD. International Journal of COPD. 2014;9(1): 871-888.

6. Caram LM, Ferrari R, Naves CR, Coelho LS, Vale SA, Tanni SE, et al. Risk factors for cardiovascular disease in patients with COPD: Mild-to-moderate COPD versus severe-to-very severe COPD. Jornal Brasileiro de Pneumologia. 2016;42(3): 179-184.

7. Marushchak M, Krynytska I, Mikolenko A, Andreychyn Y, Bodnar, Y. Chronic heart failure causes osteopathy or is osteopathy a factor in development of chronic heart failure? Asian Journal of Pharmaceutical and Clinical Research. 2018;11(1):111-115.

8. Pinto IC, Martins D. Prevalence and risk factors of arterial hypertension: A literature review. Journal of Cardiovascular Medicine and Therapeutics. 2017;1(2): 1-7.

9. Baty F, Putora PM, Isenring B, Blum T, Brutsche M. Comorbidities and burden of COPD: A population based case-control study. PLoS One. 2013;8(5): e63285.

10. Jo YS, Choi SM, Lee J, Park YS, Lee SM, Yim JJ, et al. The relationship between chronic obstructive pulmonary disease and comorbidities: A cross-sectional study using data from KNHANES 2010-2012. Respiratory Medicine. 2015;109(1): 96-104.

11. Onishi K, Yoshimoto D, Hagan GW, Jones PW. Prevalence of airflow limitation in outpatients with cardiovascular diseases in Japan. International Journal of Chronic Obstructive Pulmonary Disease. 2014;9: 563-568.

12. Shpagin IS, Kotova OS, Pospelova TI, Gerasimenko O, Shpagina L, Ermakova M. Chronic obstructive pulmonary 
disease comorbid with arterial hypertension-clinical, functional, molecular and genetic features. The Bulletin of Contemporary Clinical Medicine. 2016;9(4): 56-65 (in Russian).

13. Xi B, Shen $Y$, Yan $Y$, Mi J. Association of polymorphisms in the AGT gene with essential hypertension in the Chinese population. Journal of the Renin-Angiotensin-Aldosterone System. 2011;13(2): 282-288.

14. Ayada C, Toru Ü, Genç O, Şahin S, Turgut S, Turgut G. Angiotensinogen gene M235T and angiotensin Il-type 1 receptor gene A/C1166 polymorphisms in chronic obstructive pulmonary disease. International Journal of Clinical and Experimental Medicine. 2015;8(3): 4521-4526.

15. Kim HK, Lee H, Kwon JT, Kim HJ. A polymorphism in AGT and AGTR1 gene is associated with lead-related high blood pressure. Journal of the Renin-Angiotensin-Aldosterone System. 2015;16(4): 712-719.

16. Liu Y, Fu L, Pi L, Che D, Xu Y, Zheng H, et al. An angiotensinogen gene polymorphism ( $r s 5050$ ) Is associated with the risk of coronary artery aneurysm in southern Chinese children with Kawasaki disease. Disease Markers. 2019;7: Article ID 2849695.

17. Turgut S, Akın F, Akcılar R, Ayada C, Turgut G. Angiotensin converting enzyme I/D, angiotensinogen M235T and AT1-R A/C1166 gene polymorphisms in patients with acromegaly. Molecular Biology Reports. 2011;38: 569-576.

18. Afshariani R, Roozbeh J, Sharifian M, Ghaedi M, Samsami Dehaghani A, Ghaderi A. Association between angiotensinogen M235T polymorphism and preeclampsia in Iranian pregnant women. Journal of Family and Reproductive Health. 2014;8(4): 169-173.

19. Marta P, Tomasz F, Jan K, Przemysław A, Jacek C, Irena P. Angiotensinogen gene M235T and T174M polymorphisms in patients with morbid obesity and type 2 diabetes mellitus. Journal of Diabetes and Metabolism. 2015;6: 479.

20. Prem P, Munshi A, Mullapudi R, Sampath Kumar P, Sharath A, Anil Krishna G, et al. The M235T polymorphism of the angiotensinogen gene in South Indian patients of hypertrophic cardiomyopathy. Journal of the Renin-Angiotensin-Aldosterone System. 2010;12(3): 238-242.

21. Wang YJ, Pan Y. The M235T polymorphism in the angiotensinogen gene and myocardial infarction risk: A meta-analysis. Journal of the Renin-Angiotensin Aldosterone System. 2014;15(3): 294-300.

22. Zimermann PJ, Teixeira PJ, Nogueira MF. COPD: More treatment will translate to better breathing. Will it? Jornal Brasileiro de Pneumologia. 2019;45(1): e20190037.

23. Wu X, Yuan B, Lopez E, Bai C, Wang X. Gene polymorphisms and chronic obstructive pulmonary disease. Journal of Cellular and Molecular Medicine. 2014;18(1): 15-26.

24. Eisner MD, Anthonisen N, Coultas D, Kuenzli N, Perez-Padilla R, Postma D, et al. An Official American Thoracic Society Public Policy Statement: Novel risk factors and the global burden of chronic obstructive pulmonary disease. American Journal of Respiratory and Critical Care Medicine. 2010;182: 693-718.

25. Fedortsiv O, Brozek GM, Luchyshyn N, Kubey I, Lawson JA, Rennie DC, et al. Prevalence of childhood asthma, rhinitis, and eczema in the Ternopil region of Ukraine - Results of BUPAS study. Advances in Medical Sciences. 2012;57(2): 282-289.

26. Gilowska I, Kasper L, Bogacz K. Impact of matrix metalloproteinase 9 on COPD development in Polish patients: Genetic polymorphism, protein level, and their relationship with lung function. BioMed Research International. 2018;6417415. Available online: URL https://doi.org/10.1155/2018/6417415. [Accessed 24th March 2019].

27. Hardin M, Silverman EK. Chronic obstructive pulmonary disease genetics: A review of the past and a look into the future. Chronic Obstructive Pulmonary Disease. 2014;1(1): 33-46.

28. Kukkonen MK, Tiili E, Vehmas T, Oksa P, Piirilä P, Hirvonen A. Association of genes of protease-antiprotease balance pathway to lung function and emphysema subtypes. BMC Pulmonary Medicine. 2013;13: 36.

29. Ehteshami-Afshar S, FitzGerald JM, Doyle-Waters MM, Sadatsafavi M. The global economic burden of asthma and chronic obstructive pulmonary disease. International Journal of Tuberculosis and Lung Disease. 2016;20(1): 11-23.

30. Calverley PM, Scott S. Is airway inflammation in chronic obstructive pulmonary disease (COPD) a risk factor for cardiovascular events? Chronic Obstructive Pulmonary Disease. 2006;3(4): 233-242.

31. Fabbri LM, Luppi F, Beghé B, Rabe KF. Complex chronic comorbidities of COPD. European Respiratory Journal. 2008;31(1): 204-212.

32. Miller J, Edwards LD, Agustí A. Comorbidity, systemic inflammation and outcomes in the ECLIPSE cohort. Respiratory Medicine. 2013;107: 1376-1384.

33. Shrikrishna D, Astin R, Kemp PR, Hopkinson NS. Reninangiotensin system blockade: A novel therapeutic approach in chronic obstructive pulmonary disease. Clinical Science (Lond). 2012;123: 487-498.

34. Gonzalez MC, Cohen HW, Sealey JE, Laragh JH, Alderman MH. Enduring direct association of baseline plasma renin activity with all-cause and cardiovascular mortality in hypertensive patients. American Journal of Hypertension. 2011;24: 1181-1186.

35. Levitskiy SN, Pervukhina OA, Bebyakova NA. The role of gene polymorphisms of the renin-angiotensin system in the formation of cardiovascular pathology. Vestnik SAFU. Biomedical Sciences. 2016;4: 30-9.

36. Tsymbalyuk VI, Vasilyeva IG, Kostiuk MR, Chopik NG, Galanta O, Tsyubko OI, et al. Investigation of the association between ACE, AGT and FGB gene polymorphisms and risk of early onset of atherothrombotic ischemic stroke in Ukrainian Caucasian population. INJ. 2016;8(86): 20-26.

37. Bonfim-Silva R, Guimarães LO, Souza Santos J. Case-control association study of polymorphisms in the angiotensinogen and angiotensin-converting enzyme genes and coronary artery 
disease and systemic artery hypertension in African-Brazilians and Caucasian-Brazilians. Journal of Genetics. 2016;95: 63-69.

38. Tsai CT, Chang SN, Chang SH. Renin-angiotensin system gene polymorphisms predict the risk of stroke in patients with atrial fibrillation: A 10-year prospective follow-up study. Heart Rhythm. 2014;11: 1384-1390.

39. Fishchuk LY. Influence of gene polymorphisms of the reninangiotensin system on the risk of hypertension in women. Odessa Medical Journal. 2013;5(139): 26-30.

40. Simonyte S, Kuciene R, Medzioniene J, Dulskiene V, Lesauskaite V. Renin-angiotensin system gene polymorphisms and high blood pressure in Lithuanian children and adolescents. BMC Medical Genetics. 2017;18(1): 100.

41. Niu T, Yang J, Wang B, Chen W, Wang Z, Laird N, et al. Angiotensinogen gene polymorphisms M235T/T174M: No excess transmission to hypertensive Chinese. Hypertension. 1999;33(2): 698-702.

42. Caulfield $M$, Lavender $P$, Farrall $M$, Munroe $P$, Lawson $M$, Turner $P$, et al. Linkage of the angiotensinogen gene to essential hypertension. The New England Journal of Medicine. 1994;330(23): 1629-1633.

43. Mohana VU, Swapna N, Surender RS, Vishnupriya S, Padma T. Gender-related association of AGT gene variants (M235T and T174M) with essential hypertension - a case-control study. Clinical and Experimental Hypertension. 2012;34(1):38-44.

44. Jeunemaitre X, Soubrier F, Kotelevtsev YV, Lifton RP, Williams CS, Charru A, et al. Molecular basis of human hypertension: Role of Angiotensinogen. Cell. 1992;71(1): 169-180.
45. Sethi AA, Nordestgaard BG, Grønholdt ML, Steffensen R, Jensen G, Tybjaerg-Hansen A. Angiotensinogen single nucleotide polymorphisms, elevated blood pressure, and risk of cardiovascular disease. Hypertension. 2003;41(6): 1202-1211.

46. Kolovou V, Lagou E, Mihas C, Vasiliki G, Katsiki N, Kollia A, et al. Angiotensinogen (AGT) M235T, AGT T174M and angiotensin1-converting enzyme (ACE) I/D gene polymorphisms in essential hypertension: Effects on ramipril efficacy. The Open Cardiovascular Medicine Journal. 2015;9: 118-126.

47. Shamaa MM, Fouad H, Haroun M, Hassanein M, Hay MAA. Association between the Angiotensinogen (AGT) gene (M235T) polymorphism and essential hypertension in Egyptian patients. The Egyptian Heart Journal. 2015;67(1): 1-5.

48. Kon SS, Jolley CJ, Shrikrishna D. ACE and response to pulmonary rehabilitation in COPD: Two observational studies. BMJ Open Respiratory Research. 2017;4: e000165.

49. Simsek S, Tekes S, Oral D. The insertion/deletion polymorphism in the ACE gene and chronic obstructive pulmonary disease. Genetics and Molecular Research. 2013;12: 1392-1398.

50. Pabst S, Theis B, Gillissen A. Angiotensin-converting enzyme I/D polymorphism in chronic obstructive pulmonary disease. European Journal of Medical Research. 2009;14(4): 177-181.

51. Kanazawa H, Otsuka T, Hirata K, Yoshikawa J. Association between the angiotensin converting enzyme gene polymorphisms and tissue oxygenation during exercise in patients with COPD. Chest. 2002;121: 697-701. 